\title{
PERLUNYA MENGKAJI KEMBALI PERATURAN BANK INDONESIA TENTANG MEDIASI PERBANKAN
}

\author{
Syamsul Hoiri ${ }^{1}$
}

\section{Abstrak}

Under the Bank Indonesia regulation in year 2006 (PBI No.8/5/PBI/2006) has introduced the alternative dispute resolution in banking business. The main purpose of institution is aimed to giving more facility for simple and faster resolution through banking and lower customer dispute's. The 2006 regulation itself opens resolution methods by negotiation, conciliation, mediation, arbitration and litigation. The option to apply those methods would tend to mediation procedure. More over for middle lower banking customers and micro scale business will get more handicaps to choice litigation or arbitration. It's by considering on length and spent more cash are needed. The resolution system also offers banking mediation institute (LMP) is the competence agent to conduct mediation process but then until the end of year 2007 the LMP have not taken shape. Then under regulation of year 2008 (PBI No. 10/1/PBI/2008) temporary the resolution be handled by Directorate investigation and Banking Mediation of Bank Indonesia.

Kata kunci: hukum perbankan, peraturan bank Indonesia, mediasi, pengkajian kembali

\section{Pendahuluan}

Dalam dunia perbankan, pihak nasabah merupakan unsur yang sangat berperan sekali, mati hidupnya dunia perbankan bersandar kepada kepercayaan dari pihak masyarakat atau nasabah. ${ }^{2}$ Keberadaan aset bank

' Alumni FHUI (S1) tahun 1990. Mengikuti studi S1 pada FEUI jurusuan Akuntansi tahun 1988-1991. Bekerja di Bank Pacific sejak 1991 - 1998. Sejak 1998 - sekarang bekerja di holding company di Jakarta dengan core business Migas, Batubara dan perkebunan sawit. Selain menulis di Jurnal Hukum Bisnis, juga menulis beberapa artikel hukum dan investasi di harian Bisnis Indonesia dan Suara Pembaruan. Saat ini tengah menempuh program pascasarjana Hukum Ekonomi pada pascasarjana FHUI.

${ }^{2}$ Muhammad Djumhana, "Hukum Perbankan di Indonesia", (Bandung: PT. Citra Aditya Bhakti, 2003), hal. 282. 
dalam bentuk kepercayaan masyarakat sangat penting dijaga karena bank tidak memiliki uang tunai yang cukup untuk membayar kewajiban kepada seluruh nasabahnya sekaligus. ${ }^{3}$

Bank menyediakan produk berupa penerimaan simpanan dan pemberian kredit. Simpanan dapat ditarik nasabah setiap saat, sedangkan piutang bank hanya dapat ditagih oleh bank berdasarkan jangka waktu tertentu. Sehingga apabila terjadi krisis kepercayaan maka bisa terjadi bank kekurangan dana karena nasabah menarik simpanan mereka. Itulah sebabnya bank disebut sebagai lembaga kepercayaan. Alan Greenspan mengatakan "When confidence in the integrity of a financial institutions is shaken or its commitment to the honest conduct of business is in doubt, public trust erodes and the entire system is weakened" ". Maka wajarlah jika di berbagai belahan dunia biasanya sektor keuangan sangat diawasi oleh pemerintah (highly regulated industry) karena ada kepentingan umum yang harus dilindungi. ${ }^{5}$

Mengingat pentingnya perlindungan nasabah tersebut, BI menetapkan upaya perlindungan nasabah sebagai salah satu pilar dalam Arsitektur Perbankan Indonesia (API). API merupakan suatu kerangka dasar sistem perbankan Indonesia yang terdiri dari enam pilar, bersifat menyeluruh dan memberikan arah, bentuk dan tatanan pada industri perbankan untuk rentang waktu lima sampai sepuluh tahun ke depan. ${ }^{6}$

Adapun enam pilar API adalah: 1) struktur perbankan yang sehat; 2) sistem pengaturan yang efektif; 3) sistem pengawasan yang independen dan efektif; 4) industri perbankan yang kuat; 5) infrastruktur pendukung yang mencukupi; 6) perlindungan konsumen.

Upaya perlindungan nasabah dalam pilar keenam API dituangkan dalam empat aspek yang terkait satu sama lain dan secara bersama-sama akan dapat meningkatkan perlindungan dan pemberdayaan hak-hak nasabah. Empat aspek tersebut adalah: ${ }^{7}$

${ }^{3}$ Zulkarnain Sitompul, "Peran dan Fungsi Bank Dalam Sistem Perekonomian", $<$ http://zulsitompul.wordpress.com/>, diakses 29 November 2008.

${ }^{4}$ Ibid

5 Yunus Husein, "Pelajaran dari Krisis Keuangan Amerika", $<$ http://www.economy.okezone.com/in-dex.php/ReadStory/2008/10/07/212/151437/pelajarandari-krisis-keuangan-amerika>, diakses tanggal 7 Oktober 2008.

${ }^{6}$ Erna Priliasari, "Mediasi Perbankan Sebagai Wujud Perlindungan Terhadap Nasabah", <www.legalitas.org>, diakses 10 November 2008. 
1. Penyusunan standar mekanisme pengaduan nasabah;

2. pembentukan lembaga mediasi perbankan;

3. penyusunan standar transparansi informasi produk;

4. peningkatan edukasi untuk nasabah.

Tulisan ini selanjutnya akan memfokuskan pada aspek kedua, yaitu lembaga mediasi perbankan, dan topik permasalahan yang akan diteliti adalah sebagai berikut:

1. Bagaimana pengaturan lembaga mediasi perbankan dan apa saja kelemahannya?

2. Apa saja kelebihan mediasi perbankan dibanding alternative penyelesaian sengketa lainnya?

3. Apakah keberadaan mediasi perbankan sudah mampu melindungi kepentingan nasabah?

4. Mengapa lembaga mediasi perbankan gagal dibentuk?

5. Apakah tepat pendirian lembaga mediasi perbankan diserahkan ke asosiasi perbankan?

\section{Peraturan Mediasi Perbankan}

\section{A. PBI No. $8 / 5 / \mathrm{PBI} / 2006^{8}$}

Lembaga mediasi perbankan telah disosialisasikan melalui Peraturan Bank Indonesia (PBI) No. 8/5/PBI/2006 tanggal 30 Januari 2006 dan Surat Edaran Bank Indonesia No. 8/14/DPNP tanggal 1 Juni 2006, sehingga dengan demikian Bank Indonesia telah menjalankan fungsi mediasi perbankan sebagai sarana yang sederhana, murah dan cepat dalam hal penyelesaian pengaduan nasabah oleh bank belum dapat memuaskan nasabah dan menimbulkan sengketa antara nasabah dengan bank.

${ }^{7}$ Muliaman D. Hadad, "Perlindungan dan Pemberdayaan Nasabah Bank Dalam Arsitektur Perbankan Indonesia", <http://www.bi.go.id>, diakses 10 November 2008.

8 Peraturan Bank Indonesia No. 8/5/PBI/2006 tentang Mediasi Perbankan, Lembaran Negara RI Tahun 2006 No. 7, Tambahan Lembaran Negara RI No. 4601 


\section{Latar Belakang}

Dalam PBI No.8/5/PBI/2006 disebutkan bahwa ada tiga hal yang menjadi latar belakang perlunya mengatur mediasi perbankan dalam suatu PBI, yaitu:

a. bahwa penyelesaian pengaduan nasabah tidak selalu dapat memuaskan nasabah dan berpotensi menimbulkan sengketa di bidang perbankan antara nasabah dengan bank

b. bahwa penyelesaian sengketa di bidang perbankan yang berlarut-larut dapat merugikan nasabah dan meningkatkan risiko reputasi bagi bank;

c. bahwa penyelesaian sengketa di bidang perbankan antara nasabah dengan bank dapat dilakukan secara sederhana, murah dan cepat melalui cara mediasi.

\section{Model Mediasi Perbankan Yang Dipilih}

Sebelum dikeluarkannya PBI tentang mediasi perbankan, berdasarkan kajian BI ada lima alternatif model yang bisa dibentuk, yaitu: ${ }^{9}$

4) lembaga mediasi dibentuk BI tanpa kewenangan melakukan verifikasi dan investigasi;

5) lembaga mediasi dibentuk BI dengan kewenangan melakukan verifikasi dan investigasi;

6) lembaga mediasi dibentuk di luar BI tanpa kewenangan melakukan verifikasi dan investigasi;

7) Badan Arbitrase Perbankan Indonesia (BAPI) di luar BI yang mengakomodasi fungsi mediasi dan arbitrase;

8) BAPI di luar BI yang hanya melaksanakan fungsi arbitrase.

Lembaga mediasi yang dibentuk di luar BI diharapkan terdapat di setiap ibu kota provinsi atau minimal wilayah kerja kantor BI kelas satu dan dua. Untuk pembentukan badan arbitrase, BI masih terkendala belum diaturnya hal itu dalam UU Perbankan. ${ }^{10}$

${ }^{9}$ Faj, "BI Akan Bentuk Mediasi Perselisihan Perbankan," <http://64.203.71.11/ kompas-cetak/0407/31/finansial/1180270.htm>, diakses tanggal 31 Juli 2004.

${ }^{10} \mathrm{Ibid}$. 
Jika menelaah PBI No. 8/5/PBI/2006 dan No. 10/1/PBI/2008 terlihat bahwa model ketiga yang dipilih oleh BI. Hal ini dapat disimpulkan dari beberapa Pasal sebagai berikut:

1) mediasi adalah proses penyelesaian sengketa yang melibatkan mediator untuk membantu para pihak yang bersengketa guna mencapai penyelesaian dalam bentuk kesepakatan sukarela terhadap sebagian atau seluruh permasalahan yang disengketakan (Pasal 1 angka 5);

2) Mediasi perbankan dilakukan oleh lembaga mediasi perbankan independen yang dibentuk asosiasi perbankan (Pasal 3 ayat (1));

3) Sepanjang lembaga mediasi perbankan independen belum dibentuk, fungsi mediasi perbankan dilaksanakan oleh BI (Pasal 3 ayat (4));

4) Fungsi mediasi perbankan yang dilaksanakan oleh BI terbatas pada upaya membantu nasabah dan bank untuk mengkaji ulang sengketa secara mendasar dalam rangka memperoleh kesepakatan (Pasal 4). Yang dimaksud dengan "membantu nasabah dan bank" adalah BI memfasilitasi penyelesaian sengketa dengan cara memanggil, mempertemukan, mendengar, dan memotivasi nasabah dan bank untuk mencapai kesepakatan tanpa memberikan rekomendasi atau keputusan (Penjelasan Pasal 4).

\section{Keunggulan Mediasi Perbankan}

Dalam Penjelasan Umum PBI No. 8/5/PBI/2006 ditegaskan bahwa upaya penyelesaian sengketa antara nasabah dengan bank dapat dilakukan melalui negosiasi, konsiliasi, mediasi, arbitrase atau jalur peradilan. Akan tetapi bagi nasabah kecil dan usaha mikro akan mengalami kesulitan jika menempuh jalur arbitrase atau peradilan mengingat memerlukan waktu dan biaya yang tidak sedikit. Sengketa antara nasabah kecil dan usaha mikro dengan bank akan relatif lebih mudah diselesaikan melalui cara mediasi. ${ }^{\prime \prime}$

${ }^{11}$ Sefti Williarsih, "Perlindungan Kepentingan Nasabah dan Pentingnya Menjaga Reputasi Bank", <http://akuasih.wordpress.com/2008/03/08/mediasi-perbankan/>, diakses tanngal 8 Maret 2008. 
Hal ini disebabkan proses penyelesaian sengketa melalui mediasi perbankan murah, cepat dan sederhana, karena: ${ }^{12}$

a. tidak dipungut biaya;

b. jangka waktu proses mediasi paling lama 60 hari;

c. proses mediasi dilakukan secara informal/fleksibel.

\section{Persyaratan Pengajuan Mediasi Perbankan}

Pengajuan penyelesaian sengketa dimaksud dapat disampaikan kepada Bank Indonesia oleh nasabah atau perwakilan nasabah dengan persyaratan sebagai berikut: $:^{13}$

a. pernah diajukan upaya penyelesaian sengketa oleh nasabah kepada bank (Pasal 8 angka 2);

b. tidak sedang dalam proses atau belum pernah diputus oleh lembaga arbitrase atau peradilan, atau belum terdapat kesepakatan yang difasilitasi oleh lembaga mediasi lainnya (Pasal 8 angka 3);

c. merupakan sengketa keperdataan (Pasal 8 angka 4), dan nilai tuntutan finansial diajukan dalam mata uang rupiah dengan jumlah maksimal Rp. 500 juta (Pasal 6 ayat (1)). Jumlah tersebut dapat berupa kumulatif dari kerugian finansial yang telah terjadi pada nasabah, potensi kerugian karena penundaan atau tidak dapat dilaksanakannya transaksi keuangan nasabah dengan pihak lain, dan/atau biaya-biaya yang telah dikeluarkan nasabah untuk mendapatkan penyelesaian sengketa. Nasabah tidak dapat mengajukan tuntutan finansial yang diakibatkan oleh kerugian immaterial (Pasal 6 ayat (2)). Yang dimaksud kerugian immaterial antara lain adalah kerugian karena pencemaran nama baik dan perbuatan tidak menyenangkan;

d. Belum pernah diproses dalam mediasi perbankan yang difasilitasi oleh BI (Pasal 8 angka 5);

e. Batas waktu pengajuan adalah paling lambat 60 hari kerja yg dihitung sejak tanggal surat hasil hasil penyelesaian

12 "Ayo Ke Bank, Mediasi Perbankan", <http://www.bi.go.id>, diakses tanggal 28 November 2008.

13 Wahyu Kuncoro, "Lembaga Mediasi Perbankan", <http://advokatku.blogspot. com/2007/09/lembaga-mediasi-perbankan.html>, diakses tanggal 14 September 2007. 
pengaduan yang disampaikan bank kepada nasabah (Pasal 8 angka 6);

f. Nasabah mengajukan penyelesaian sengketa kepada lembaga mediasi perbankan secara tertulis dan dilengkapi dokumen pendukung (Pasal 8 angka 1). Permohonan yang dilengkapi dokumen pendukung disampaikan kepada Direktorat Investigasi dan Mediasi Perbankan Bank Indonesia (Pasal 15).

\section{Proses Mediasi Perbankan}

a. sebelum melakukan proses mediasi, nasabah dan bank harus menandatangani perjanjian mediasi yang memuat (Pasal 9):

i. kesepakatan untuk memilih mediasi sebagai alternative penyelesaian sengketa; dan

ii. persetujuan untuk patuh dan tunduk pada aturan mediasi.

b. Bank Indonesia selaku mediator akan memfasilitasi pertemuan antara bank dengan nasabah guna mencari penyelesaian. Dalam pertemuan tersebut, mediator akan:

i. Bersikap netral;

ii. Memotivasi para pihak untuk menyelesaikan sengketa;

iii. Tidak memberikan rekomendasi atau keputusan. Hasil penyelesaian terhadap sengketa merupakan kesepakatan antara nasabah dengan bank.

c. Apabila dicapai kesepakatan, maka nasabah dan bank akan menandatangani akta kesepakatan. Pelaksanaan proses mediasi sampai dengan ditandatanganinya Akta kesepakatan dilakukan dalam jangka waktu maksimal 30 hari kerja sejak nasabah atau perwakilan nasabah dan bank menandatangani perjanjian mediasi (Pasal 11 ayat (1)). Jangka waktu tersebut dapat diperpanjang sampai dengan 30 hari kerja berikutnya berdasarkan kesepakatan nasabah/perwakilan nasabah dan bank (Pasal 11 ayat (2));

d. Apabila tidak dicapai kesepakatan, nasabah dapat melakukan upaya penyelesaian lanjutan melalui arbitrase atau pengadilan. 


\section{Sanksi Bagi Bank}

Bank akan dikenakan sanski administratif sesuai Pasal 52 UU No. 7/1992 tentang Perbankan sebagaimana telah diubah dengan UU No. 10 tahun 1998, berupa teguran tertulis dan dapat diperhitungkan dalam komponen penilaian tingkat kesehatan bank, apabila:

a. bank tidak memenuhi panggilan Bank Indonesia dalam hal nasabah/perwakilan nasabah mengajukan penyelesaian sengketa kepada Bank Indonesia;

b. bank tidak mengikuti dan mentaati perjanjian mediasi yang telah ditandatangani oleh nasabah / perwakilan nasabah dan bank;

c. bank tidak melaksanakan hasil penyelesaian sengketa perbankan antara nasabah dengan bank yang telah disepakati dan dituangkan dalam akta kesepakatan;

d. bank tidak mempublikasikan kepada nasabah adanya sarana alternative penyelesaian sengketa di bidang perbankan dengan cara mediasi.

\section{B. PBI No. $10 / 1 / \mathrm{PBI} / 2008^{14}$}

Sesuai Pasal 3 ayat (2) PBI No. 8/5/PBI/2006, pembentukan lembaga mediasi perbankan independen selambat-lambatnya 31 Desember 2007. Namun karena hingga akhir tahun 2007 belum juga terbentuk lembaga mediasi perbankan, maka Bank Indonesia memperbarui PBI tentang mediasi perbankan dengan mengeluarkan PBI No. 10/1/PBI/2008 tanggal 29 Januari 2008 tentang Perubahan Atas Peraturan Bank Indonesia No. 8/5/PBI/2006 tentang Mediasi Perbankan.

Perubahan yg diatur dalam PBI No. 10/1/PBI/2008 meliputi:

1. menghapus Pasal 3 ayat (2) PBI No. 8/5/PBI/2006 mengenai pembentukan lembaga mediasi perbankan independen selambatlambatnya 31 Desember 2008. Jadi dengan keluarnya PBI No. 10/1/PBI/2008, maka tidak ada lagi penentuan batas waktu pembentukan lembaga mediasi perbankan;

${ }^{14}$ Peraturan Bank Indonesia No. 10/1/PBI/2008 tentang Perubahan Atas Peraturan Bank Indonesia No. 8/5/PBI/2006 tentang Mediasi Perbankan, Lembaran Negara RI Tahun 2008 No. 10, Tambahan Lembaran Negara RI No. 4808. 
2. merubah pasal 15 PBI No. 8/5/PBV/2006 mengenai alamat Direktorat Investigasi dan Mediasi Perbankan Bank Indonesia dari semula di Menara Radius Prawiro Lantai 19 Jalan MH Thamrin No.2 Jakarta 10110 menjadi Jalan MH Thamrin Nomor 2 Jakarta 10350 .

\section{Kelemahan Peraturan Mediasi Perbankan}

\section{A. Pembentukan LMP diserahkan ke asosiasi}

Lembaga mediasi perbankan (LMP) dibentuk oleh asosiasi perbankan (Pasal 3 ayat (1) PBI No. 10/1/PBI/2008). Menurut penulis, jika pembentukan LMP diserahkan ke asosiasi perbankan, maka akan mengalami kesulitan. Ini terbukti hingga 31 Desember 2007 LMP belum juga terbentuk. Setidaknya ada 4 penyebab:

1. target pemenuhan modal minimum bank umum menjadi Rp. $\mathbf{8 0}$ milyar pada akhir tahun 2007 tampaknya berdampak pada sebagian kegiatan perbankan nasional. Akibatnya, beberapa proyek berbasis perbankan menjadi terbengkalai, salah satunya adalah pembentukan lembaga mediasi perbankan. ${ }^{15}$

Sedianya lembaga bentukan beberapa organisasi perbankan nasional itu, dijadwalkan harus sudah kelar pada akhir tahun 2007. Namun peliknya masalah perbankan di awal tahun 2007 dan rencana konsolidasi perbankan pada 2008 , memaksa organisasi perbankan mengendurkan niatnya untuk membentuk badan independen tersebut. Alasannya, bank-bank sedang fokus menyiapkan dana Rp. 80 miliar supaya tidak di black list oleh bank sentral. ${ }^{16}$

Direktur Direktorat Investigasi dan Mediasi Perbankan BI Achmad Fuad mengatakan, penambahan modal sebesar itu, memang cukup memberatkan bagi bank. Wajar jika beberapa bank sepakat untuk menunda rencana pembentukan lembaga mediasi tersebut. ${ }^{17}$

15 "Lembaga Mediasi Perbankan Gagal Dibentuk Tahun Ini", $<$ http://www.hukumonline.com/detail.asp?id=17353\&cl=Berita>, diakses tanggal 13 Agustus 2008 .

${ }^{16} \mathrm{Ibid}$. 
2. alasan modal juga menjadi penyebab penundaan terbentuknya LMP. Pasalnya, jika LMP terbentuk, maka bank juga wajib menyalurkan dananya ke LMP. Kondisi yang berbarengan inilah yang membuat rencana itu terpaksa ditunda. ${ }^{18}$

3. Masih banyak yang harus dipikirkan untuk membentuk LMP. Mulai dari masalah badan hukum, mediator hingga ke masalah teknis pelaksanaannya di lapangan. Sementara, menurut Achmad, Perbanas nyata-nyata mengaku belum siap sama sekali untuk membentuk lembaga itu. ${ }^{19}$

Sekjen Perbanas Farid Rahman mengakui, hingga kini Perbanas belum sanggup membentuk lembaga mediasi seperti yang diharapkan BI. Pembentukan lembaga mediasi masih terkendala faktor sumber daya manusia dan pendanaan. ${ }^{20}$

4. Adanya persoalan di tingkat komunikasi dan perlunya kesepakatan mengenai biaya yang dikeluarkan untuk operasional lembaga mediasi independen. "Apakah kewajiban bank besar dengan kecil sama ?" Itu belum disepakati," ujar Ketua Asosiasi Bank Pembangunan Daerah (Asbanda) Winny E. Hasan. ${ }^{21}$

Berdasarkan uraian di atas, maka dapat dimaklumi apabila ada beberapa kajian dari kalangan akademis, seperti dari UGM dan USU, yang meminta agar pembentukan lembaga itu dilakukan oleh BI. Dan, ada juga yang menginginkan agar mediasi perbankan tetap dilaksanakan oleh BI ${ }^{22}$ Dan dapat dimaklumi pula apabila PBI No. 10/1/PBI 2008 tidak berani menetapkan batas waktu pendirian LMP, berbeda dengan PBI No. 8/5/PBI/2006 yang menegaskan batas waktu 31 Desember 2007 , tapi ternyata tidak terwujud.

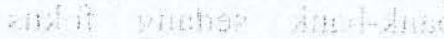
tion in hist.

${ }^{17}$ Ibid.
${ }^{18}$ Ibid.
${ }^{19}$ Ibid.
${ }^{20}$ Yudhie Thirzano. "Menantı Lembaga Mediasi Independen, Masih Terkendala
SDM dan Pendanaan". <http://www.surya.co.id/web>, diakses tanggal I Maret 2008.

1. Sut 'BI Desak Perbankan Segera Bentuk Lembaga Mediasi" $<$ http://www.hukumonline.com/detail.asp?id $=18483 \& \mathrm{cl}=$ Berita $>$, diakses tanggal 5 Februari 2008.

22 “Lembaga Mediası Perbankan Gagal Dibentuk Tahun Ini”, Loc.Cit. 


\section{B. Terlaksananya Mediasi Perbankan Tergantung Bank}

Yang mengajukan gugatan ke mediasi perbankan adalah nasabah atau perwakilan nasabah, namun sebenarnya dapat tidaknya penyelesaian sengketa perbankan melalui lembaga mediasi perbankan sangat bergantung pada itikad bank. Bank lah yang menentukan apakah suatu sengketa dapat diselesaikan melalui mediasi perbankan ataukah cara lain. Hal ini tercermin dari hal-hal sebagai berikut :

1. pengajuan penyelesaian sengketa paling lambat 60 hari kerja sejak tanggal surat hasil penyelesaian pengaduan yang disampaikan bank kepada nasabah (Pasal 8 butir 6 PBI No. 8/5/PBI/2006). Dalam praktik, keluhan-keluhan nasabah umumnya ditanggapi secara lisan oleh bank, atau bahkan tidak ditanggapi sama sekali. ${ }^{23}$ Sehingga ketentuan Pasal 8 butir 6 PBI No. 8/5/PBI/2006 tersebut mempersulit nasabah / wakil nasabah untuk mengajukan penyelesaian sengketa ke LMP.

2. Proses mediasi dilaksanakan setelah nasabah/perwakilan nasabah dan bank menandatangani perjanjian mediasi yang memuat : a) kesepakatan untuk memilih mediasi sebagai alternative penyelesaian sengketa dan b) persetujuan untuk patuh dan tunduk pada aturan mediasi yang ditetapkan oleh BI (Pasal 9 ayat (1) PBI No. 8/5/PBI/2006). Ketentuan ini akan menyulitkan bagi nasabah/wakil nasabah untuk mengajukan penyelesaian sengketa melalui LMP dalam hal bank tidak mau menandatangani perjanjian mediasi. Oleh karena itu adalah lebih baik jika sejak awal nasabah dan bank sudah sepakat untuk menyelesaikan sengketa melalu mediasi perbankan dengan mencantumkan klausula mediasi dalam perjanjian pokok, yakni dalam perjanjian kredit atau dalam buku rekeningan simpanan nasabah. Inilah mandatory mediation yang didasarkan pada kesepakatan bersama oleh para pihak. Sebagai kesepakatan bersama, ketentuan tersebut akan berlaku sebagai UU bagi para pihak yang membuatnya (Pasal 1338 jo. Pasal 1320 KUHPerdata). ${ }^{24}$ Dengan

${ }^{23}$ Khotibul Umam, "Catatan Kritis Terhadap PBI No. 8/5/PBI/2006 tentang Mediasi Perbankan Sebagai Alternatif Penyelesaian Sengketa dan Rekomendasi Dalam Implementasinya Ke depan", <http://khotibwriteinc.blogspot.com/2008/03/mediasiperbankan.html>, diakses tanggal 28 Maret 2008.

${ }^{24}$ Felix Oentoeng Soebagio, Mediasi Sebagai Alternatif Penyelesaian Sengketa di bidang Perbankan, Bahan Diskusi Terbatas "Pelaksanaan Mediasi Perbankan oleh Bank 
mencantumkan klausula mediasi dalam perjanjian pokok, menyebabkan bank maupun nasabah terikat untuk melaksanakannya semata-mata karena memang diperjanjikan (asas pacta sunt servanda).

\section{Efektivitas Akta Kesepakatan Mediasi}

Bank wajib melaksanakan hasil penyelesaian sengketa perbankan antara nasabah dengan bank yang telah disepakati dan dituangkan dalam Akta Kesepakatan (Pasal 13 PBI No. 8/5/PBI/2006). Namun tidak ada ketentuan mengenai tenggang waktu kapan bank harus melaksanakan kesepakatan tersebut. Sebagai perbandingan, dalam Pasal 6 angka 8 UU No. 30/1999 tentang Arbitrase dan Alternatif Penyelesaian Sengketa, diatur bahwa kesepakatan mediasi wajib dilaksanakan dalam waktu paling lama 30 hari sejak didaftarkan di Pengadilan Negeri. ${ }^{25}$

Selain itu, efektivitas dari sebuah akta kesepakatan hasil mediasi tentu sangat bergantung dari itikad baik bank untuk mentaati hasil kesepakatan tersebut. Secara teori semestinya tidak mungkin ada kesepakatan damai yang tidak dipatuhi karena untuk mencapai kesepakatan damai sudah merupakan kerelaan dari para pihak untuk win-win solution, apalagi tidak ada paksaan dari pihak ketiga dalam menentukan hasil akhir dari proses perundingan.

UU No. 30 tahun 1999 tentang Arbitrase dan Alternatif Penyelesaian Sengketa dalam Pasal 6 angka 7 secara jelas menyatakan bahwa kesepakakatan penyelesaian sengketa melalui mediasi adalah final dan mengikat para pihak untuk dilaksanakan dengan itikad baik. Jadi, pelaksanaan kesepakatan sangat tergantung dari itikad baik para pihak.

Masalahnya, sejauh mana kesepakatan ini mempunyai kekuatan hukum mengikat. Apabila sudah ada kesepakatan, tapi ternyata salah satu pihak wanprestasi, maka bagaimana agar pihak yang wanprestasi tersebut dituntut untuk melakukan apa yang menjadi prestasi. Dengan adanya kekuatan mengikat, kesepakatan tidak perlu lagi diulang atau diperiksa oleh pengadilan atau arbitrase. Di sini, Negara melalui UU mempunyai peran yang sangat penting, yaitu mengupayakan agar akta

Indonesia dan Pembentukan Lembaga Independen Mediasi Perbankan", kerjasama Magister Hukum Bisnis dan Kenegaraan UGM dan BI, 21 Maret 2007, hal 5-6.

${ }^{25}$ UU RI No. 30/1999 tentang Arbitrase dan Alternatif Penyelesaian Sengketa, LN RI Tahun 1999 No. 138, Tambahan LN RI No. 3872. 
kesepakatan hasil mediasi dapat disamakan dengan putusan pengadilan atau putusan arbitrase, dimana kesepakatan tersebut mempunyai kekuatan eksekutorial agar efisiensi dalam hal waktu dan biaya dapat dicapai. Hal ini sebetulnya bukan hal yang aneh mengingat dalam hukum acara perdata, akta perdamaian pun dapat dimintakan penetapan.

\section{Pro \& Kontra Mediasi Perbankan Dilaksanakan BI}

Pembentukan lembaga mediasi hingga kini belum terwujud. Karena itu, BI menerbitkan PBI No. 10/1/PBI/2008 tentang Perubahan Atas PBI No. 8/5/PBI/2006. Dalam PBI terbaru ini, fungsi mediasi perbankan tetap di tangan BI sampai terbentuknya lembaga independen. ${ }^{26}$

Berkenaan dengan pelaksanaan fungsi mediasi perbankan oleh BI ataukah oleh lembaga mediasi perbankan, ada dua pendapat yang berkembang, yaitu yang pro dan kontra. Selain itu juga akan dipaparkan bagaimana pendapat BI mengenai siapa yang sebaiknya melaksanakan fungsi mediasi perbankan.

\section{A. Pendapat yang Kontra}

Bank Indonesia mendesak perbankan agar menyelesaikan sengketa dengan nasabahnya. Deputi Gubernur Bank Indonesia Muliaman D. Hadad mengatakan, hingga saat ini Bank Indonesia masih menjadi mediator bagi sengketa perbankan. Dia menegaskan pembentukan lembaga mediasi perbankan amat mendesak. Dengan begitu perbankan akan lebih memperhatikan kepentingan nasabah. Namun tidak semua bank siap membentuk lembaga mediasi ini. Padahal ini bisa menjadi kekuatan bagi bank sendiri di tengah persaingan usaha dan meningkatkan loyalitas nasabah. ${ }^{27}$

Mantan Direktur Investigasi dan Mediasi Perbankan BI Achmad Fuad mengatakan, mediasi bukanlah tugas dari BI. "Tugas BI yang sebenarnya adalah menjaga stabilitas moneter," ujar Achmad yang kini menjabat Direktur Hukum BI. ${ }^{28}$

${ }^{26}$ Yudhie Thirzano, Loc. Cit.

${ }^{27}$ Ezther Lastania, "Perbankan Didesak Atasai Sengketa", <http://www.tempo/co.id /hg/ekbis/2008/03/31/brk,2008331-120145,id.html>, diakses tanggal 31 Maret 2008. 
Pendapat Achmad didukung oleh Harry Azhar Azis. Anggota Komisi IX (bidang keuangan dan perbankan) DPR dari Fraksi Partai Golkar ini melihat fungsi mediasi perbankan kurang tepat dilakoni oleh BI. Menurutnya, BI telah keluar jalur jika ikut mengurusi soal mediasi. Pasalnya, BI adalah regulator bukan implementator yang dapat memasuki wilayah pelaku usaha seperti mediasi perbankan. "saya kira lebih bagus dijalankan oleh asosiasi, kalau dijalankan oleh $\mathrm{BI}$, maka dia mengambil wilayah yang bukan domeinnya lagi," jelas Harry kepada hukumonline. ${ }^{29}$

Selain itu, kata Harry, jika fungsi mediasi dipegang oleh BI, maka rawan terjadi conflict of interest. Berbeda jika dilakukan oleh lembaga independen bentukan asoasiasi perbankan. Menurutnya, konflik tersebut dapat dihindari karena semua komponen dalam asosiasi ikut dilibatkan. "Kalau asosiasi yang buat, maka semua komponen bersatu dalam kelompok asosiasi. Artinya tentu semakin baik dan tata beracaranya menguntungkan semua pihak," imbuhnya.

Ketua Yayasan Lembaga Konsumen Indonesia Indah Suksmaningsih menyatakan lembaga mediasi perbankan sebaiknya berasal dari lembaga independent. "Sebaiknya lembaga mediasi perbankan merupakan lembaga independen yang murah, yang tidak dibiayai oleh Negara," kata Indah. Dia juga meminta agar pembentukan lembaga mediasi perbankan cepat direalisasikan. ${ }^{30}$

\section{B. Pendapat Yang Pro}

Berbeda dengan pendapat di atas, Ketua Badan Arbitrase Nasional Indonesia (BANI), Prof. Priyatna Abdurrasyid, tak setuju jika lembaga mediasi perbankan disapih dari BI. Di bawah BI, kata dia, lembaga itu akan jauh lebih efektif ketimbang dijalankan oleh asosiasi perbankan. "Saya setuju lembaga mediasi perbankan di BI. Soalnya BI punya wibawa," ujar mantan wakil jaksa agung era Orde Baru ini. Kalau ada nasabah yang dikecewakan oleh bank, perkarakan saja ke BI. "Mana ada bank yang berani nolak kalau BI yang manggil," kata Priyatna.

Bagi mereka yang mendukung fungsi mediasi perbankan diperankan oleh $\mathrm{BI}$, maka aturan yang menyerahkan pembentukan dan

28 Sut, "BI Lebih Punya Wibawa", <http://www.hukumonline.com/detail.asp? id=20195\&cl=Berita $>$, diakses tanggal 30 September 2008 .

${ }^{29}$ Ibid.

${ }^{30}$ Ezther Lastania, Loc. Cit. 
pelaksanaan lembaga mediasi perbankan ke asosiasi perbankan merupakan kekurangan dari peraturan BI tentang mediasi perbankan yang seharusnya diperbaiki.

\section{Pendapat BI}

Di tengah pro dan kontra atas peran mediasi perbankan yang diemban oleh BI, BI sendiri berancang-ancang untuk melepas Lembaga Mediasi Perbankan (LMP) menjadi Lembaga Mediasi Perbankan Independen (LMPI). Tapi pelepasan LMPI masih harus melalui serangkaian kajian untuk menemukan formula dan mekanisme terbaik. $^{31}$

"Saat ini BI sangat terbuka untuk menerima kritik dan masukan, baik yang terkait dengan pelaksanaan mediasi maupun yang terkait dengan rencana pembentukan lembaga mediasi perbankan independent," kata Deputi Gubernur BI Muliaman D Hadad. BI bukan hanya mengundang kalangan akademisi, tapi juga Lembaga Sosial Masyarakat (LSM) dan asosiasi yang pedul terhadap perlindungan hak-hak konsumen. ${ }^{32}$

Menilik praktik yang berlaku di Negara-negara mapan, LMPI diserahkan kepada asosiasi perbankan. Ini dalam rangka menjaga independensi dan transparansi proses mediasi. Sayangnya, infrastruktur industri perbankan dalam negeri masih perlu penyempurnaan. Karenanya menurut Muliaman, LMP belum akan dilepas dari BI dalam waktu dekat. "Praktik mediasi di perbankan baru berjalan dua tahun. Kita akan lepas lembaga mediasi ketika industri siap," tutur Muliaman.

Senada dengan Muliaman, Deputi Direktur Direktorat Investigasi dan Mediasi Perbankan BI Purwantari Budiman mengatakan, lembaga mediasi perbankan harus dibentuk kalangan perbankan agar lembaga itu lebih independen. Dalam PBI terbaru, tidak tercantum lagi tenggat waktu peralihan peran mediasi perbankan dari BI ke lembaga independen. Sehingga, terbentuknya lembaga mediasi tergantung pada inisiatif kalangan perbankan, melalui asosiasi-asosiasi perbankan.

31 Muchamad Ghufron, "Lembaga Mediasi Lepas Dari BI", $<$ http://jurnalnasional.com/med=Koran\%20Harian\&sec=Ekonomi\%20Makro\&rbrk=\&id=>, diakses tanggal 1 April 2008.

${ }^{32}$ Ibid. 
Terserah asosiasi perbankan mana yang bisa membentuk, yang penting independen, kata Purwantari belum lama ini di Surabaya. ${ }^{33}$

Di Indonesia terdapat beberapa asosiasi terkait perbankan antara lain, Perhimpunan Bank-bank swasta nasional Indonesia (Perbanas), Asosiasi Bank Daerah (Asbanda), Asosiasi Bank Syariah Indonesia (Asbisindo), serta asosiasi profesi seperti Ikatan Bank Indonesia (IBI) ${ }^{34}$

Namun pada kesempatan lain, Purwantari Budiman menyatakan bahwa $\mathrm{BI}$ ingin menangani penyelesaian sengketa antara nasabah dan bank melalui jalur non litigasi, karena sekaligus menjadi upaya peningkatan perlindungan nasabah. Menurutnya, selain melindungi kepentingan nasabah, bila penanganan sengketa tersebut di tangan bank sentral, kerahasiaan data terjamin. Bila ditangani BI maka upaya mediasi juga bermanfaat sebagai sarana monitoring BI kepada bankbank. Ujungnya tentu pada perlindungan nasabah dan akhirnya kualitas layanan bank membaik. ${ }^{35}$

Menurut Purwantari, soal kredibilitas sebagai lembaga mediasi, BI tidak perlu diragukan lagi. Berbeda halnya dengan lembaga mediasi di luar BI, masyarakat harus yakin dengan kredibilitasnya untuk menyelesaikan sengketa.

\section{Praktik Mediasi Perbankan}

Saat ini, mediasi perbankan memang masih dijalankan oleh BI. Bukannya tanpa sebab BI membentuk direktorat mediasi. Pasalnya, banyak penyelesaian sengketa di bidang perbankan yang berlarut-larut sehingga merugikan nasabah dan meningkatkan risiko reputasi bagi bank.

Di BI, mekanisme penyelesaian sengketa antara nasabah dan bank ditempuh melalui dua tahap. Pertama, bank wajib menyelesaikan terlebih dahulu sengketa dengan nasabahnya sesuai PBI No. 7/7/PBI/2005 tentang Penyelesaian Pengaduan Nasabah. Kedua, apabila sengketa belum dapat diselesaikan dengan baik, nasabah bank dapat mengajukan permohonan penyelesaian sengketa melalui mediasi yang difasilitasi oleh BI.

${ }^{33}$ Yudhie Thirzano, Loc. Cit.

${ }^{34}$ Ibid.

35 "BI Ingin Tangani Sengketa Nasabah", <http://web.bisnis.com/edisi-cetak/edisiharian/keuangan/lid38577.html>, diakses tanggal 12 Januari 2008. 
Selama setahun lembaga ini terbentuk, BI mencatat angka pengaduan nasabah terhadap bank umum selama enam bulan pertama tahun 2007 mencapai 64 ribu pengaduan, dengan komposisi sebagai berikut: ${ }^{36}$

1. Sebagian besar pengaduan terkait system pembayaran perbankan masih mendominasi dengan 62.858 kasus atau sekitar 97,78\% dari total aduan yang dilayangkan oleh nasabah;

2. pengaduan nasabah di bidang penghimpunan dana sebanyak 877 kasus atau 1,36 persen;

3. penyaluran dana tercatat 343 kasus atau 0,53 persen;

4. produk kerja sama sebanyak 189 kasus atau 0,29 persen; dan

5. produk lainnya sebanyak 21 aduan atau 0,03 persen.

Dari seluruh pengaduan itu, permintaan penyelesaian dengan cara mediasi sebanyak 200 kasus. Sampai akhir 2007, BI telah menyelesaikan 90 persen kasus. Sisanya sedang dalam proses. Minimnya jumlah pengaduan yang berlanjut ke mediasi, karena bank lebih memilih langsung menyelesaikan pengaduan nasabah. Bank-bank telah menyelesaikan dengan baik. Pengaduan selesai pada fase pertama sehingga nama baik bank terjaga, ujar Purwantari Budiman, deputi Direktur Direktorat Investigasi dan Mediasi $\mathrm{BI}^{37}$

Adapun 200 kasus mediasi, perinciannya sebagai berikut: ${ }^{38}$

1. system pembayaran 44 persen;

2. penyaluran dana 17 persen;

3. produk kerjasama 17 persen;

4. Penghimpunan dana 15 persen;

5. lainnya 7 persen.

Meski tidak sebanyak di tahun 2007, namun lembaga mediasi perbankan tetap kebanjiran "order" dari nasabah. Data terakhir BI menyebutkan, penanganan kasus mediasi sejak Januari-Juni 2008 adalah 158 kasus. Dari jumlah tersebut sebanyak 89 kasus selesai tanpa mediasi, 60 kasus sedang diproses, 6 kasus diselesaikan oleh bank, dan 3 kasus diselesaikan lewat mediasi. ${ }^{39}$

${ }^{36}$ Tomi Sujatmiko, Mencari Bentuk Ideal Lembaga Mediasi Perbankan Masa Depan, "Koran Sindo", 7 Januari 2008.

${ }^{37}$ Habibur Rahman, Perbankan Gagal Bentuk Lembaga Mediasi, "Surya Online", 11 Januari 2008.

${ }^{38}$ Ibid. 
Adapun perincian 158 kasus tersebut adalah sebagai berikut :

1. penghimpunan dana 26 kasus;

2. penyaluran dana 66 kasus;

3. system pembayaran 41 kasus;

4. produk lainnya 5 kasus;

5. di luar pemasalahan produk perbankan 20 kasus.

Banyak kasus yang diselesaikan melalui lembaga mediasi perbankan pada tahun 2007 dan 2008 sebagaimana diuraikan di atas menjadi bukti bahwa penyelenggaraan mediasi perbankan memang dibutuhkan. Sengketa perbankan jika tidak dimediasi dengan baik dan profesional, dapat mendorong nasabah melakukan gugatan perdata, pidana atau publikasi negatif sehingga berpotensi merusak reputasi bank. ${ }^{40}$

\section{Penutup}

Pertama, bagi nasabah kecil dan usaha mikro akan mengalami kesulitan jika menempuh jalur arbitrase atau peradilan mengingat memerlukan waktu dan biaya yang tidak sedikit. Sengketa antara nasabah kecil dan usaha mikro dengan bank akan relatif lebih mudah diselesaikan melalui cara mediasi. Hal ini disebabkan proses penyelesaian sengketa melalui mediasi perbankan murah, cepat dan sederhana, karena:

1. tidak dipungut biaya;

2. jangka waktu proses mediasi paling lama 60 hari;

3. proses mediasi dilakukan secara informal/fleksibel.

Kedua, bank sedapat mungkin menyelesaikan sengketa dengan nasabah secara internal (fase 1), shg nasabah tidak perlu lagi membawa sengketa ke mediasi perbankan BI (fase 2). Akan tetapi dari penjelasan pada bab V terlihat bahwa masih banyak kasus sengketa perbankan yang tidak dapat diselesaikan oleh perbankan, sehingga harus diselesaikan melalui mediasi perbankan. Ini juga membuktikan bahwa keberadaan lembaga mediasi perbankan memang dibutuhkan untuk menjaga kepercayaan nasabah dan reputasi bank.

\footnotetext{
${ }^{39}$ Sut, Loc. Cit.
}

40 Tularji, "Lembaga Mediasi, Sengketa Nasabah vs Bank", $<$ http://web.bisnis.com/>, diakses tanggal 22 Februari 2008. 
Ketiga, pembentukan lembaga mediasi perbankan sebaiknya tidak diserahkan ke asosiasi perbankan, karena akan berlarut-larut sebagaimana dipaparkan pada Bab III huruf A di atas.

Keempat, ada beberapa kelemahan dalam PBI tentang Mediasi Perbankan seperti yang diuraikan dalam bab III, yang perlu ditindaklanjuti agar tujuan didirikannya lembaga mediasi perbankan benar-benar terwujud secara utuh. Juga agar spirit dibentuknya lembaga mediasi perbankan yang menginginkan nasabah tidak dirugikan karena penyelesaian sengketa yang berlarut-larut, benar-benar dapat dirasakan dan dinikmati oleh nasabah/konsumen. Apalagi bila mengingat UU No. 7/1992 tentang Perbankan sebagaimana diubah dengan UU No. 10/1998 hanya menyebutkan secara sumir aspek perlindungan konsumen sebagaimana terlihat dari Pasal 29 ayat (3) dan (4) serta UU No. 8/1999 tentang Perlindungan Konsumen, khususnya Pasal 18, dirasakan tidak memadai, ${ }^{41}$ maka menurut penulis, sewajarnyalah kelemahan-kelemahan PBI tersebut ditinjau kembali dalam rangka memberikan perlindungan konsumen/nasabah yang lebih baik.

Kelima, fungsi mediasi perbankan akan lebih baik dan efektif jika dilaksanakan oleh BI, karena:

1. Selain upaya meningkatkan perlindungan nasabah, bila penanganan sengketa tersebut di tangan bank sentral, kerahasiaan data terjamin;

2. Bila ditangani BI maka upaya mediasi juga bermanfaat sebagai sarana monitoring BI kepada bank-bank. Ujungnya tentu pada perlindungan nasabah dan akhirnya kualitas layanan bank membaik;

3. soal kredibilitas sebagai lembaga mediasi, BI tidak perlu diragukan lagi. Berbeda halnya dengan lembaga mediasi di luar BI, masyarakat harus yakin dengan kredibilitasnya untuk menyelesaikan sengketa;

4. BI lebih punya wibawa, karena tidak ada bank yang berani menolak kalau BI yang memanggil.

Keenam, mediasi perbankan oleh BI tidak bertentangan dengan tugas BI. Meskipun di atas dipaparkan, ada yang berpendapat bahwa fungsi mediasi perbankan kurang tepat dilakoni oleh BI karena BI telah keluar jalur jika ikut mengurusi soal mediasi. Pasalnya, BI adalah regulator bukan implementator yang dapat memasuki wilayah pelaku usaha seperti mediasi perbankan. Sehingga mediasi perbankan lebih bagus dijalankan oleh asosiasi

41 Dian Ediana Rae, "Transaksi Derivatif dan Masalah Regulasi Ekonomi di Indonesia”, (Jakarta : PT. Elex Media Komputindo, 2008), hal. 20-21. 
perbankan, kalau dijalankan oleh BI, maka dia mengambil wilayah yang bukan domeinnya lagi.

Namun jika melihat lebih jauh sasaran utama BI adalah menjaga stabilitas nilai tukar rupiah, dimana untuk itu BI bertanggung jawab untuk: ${ }^{42}$

1. merumuskan dan mengimplementasikan kebijakan moneter;

2. memelihara dan menjaga kelancaran system pembayaran; dan

3. mengawasi dan mengatur bank.

Maka fungsi mediasi perbankan yang dilaksanakan oleh BI adalah dalam rangka mengatur dan mengawasi bank (sebagai regulator). Menurut Deputi Direktur Direktorat Investigasi dan Mediasi Perbankan BI Purwantari Budiman bila ditangani BI maka upaya mediasi juga bermanfaat sebagai sarana monitoring BI kepada bank-bank. Ujungnya tentu pada perlindungan nasabah dan akhirnya kualitas layanan bank membaik. ${ }^{43}$

Menurut penulis, peran BI menjalankan fungsi mediasi perbankan adalah bukan sebagai implementator, tetapi sebagai regulator. Hal ini dapat disimpulkan dari hal-hal berikut:

1. Fungsi mediasi perbankan yang dilaksanakan oleh BI terbatas pada upaya membantu nasabah dan bank untuk mengkaji ulang sengketa secara mendasar dalam rangka memperoleh kesepakatan (Pasal 4 PBI No. 8/5/PBI/2006). Yang dimaksud membantu nasabah dan bank adalah BI memfasilitasi penyelesaian sengketa dengan cara memanggil, mempertemukan, mendengar dan memotivasi nasabah dan bank untuk mencapai kesepakatan tanpa memberikan rekomendasi atau keputusan (Penjelasan Pasal 4).

2. Sanksi yang dikenakan bagi bank yang tidak melaksanakan akta kesepakatan hasil mediasi perbankan adalah sanksi administratif berupa teguran tertulis dan dapat diperhitungkan dalam komponen penilaian tingka kesehatan bank (Pasal 16 PBI No. 8/5/PBI/2006).

3. berbeda dengan hakim dan Arbiter, mediator tidak dalam posisi untuk memutus sengketa para pihak. ${ }^{44}$

4. Tujuan utama mediasi adalah mencarikan jalan keluar / alternative penyelesaian atas sengketa yang timbul yang disepakati dan dapat

${ }^{42}$ Sulad Sri Hardanto, "Manajemen Risiko bagi Bank Umum", Cet. II, (Jakarta: PT. Elex Media Komputindo, 2007), hal. 46.

43 "BI Ingin Tangani Sengketa Nasabah", Loc. Cit.

${ }^{44}$ Felix Oentoeng Soebagio, Op. Cit, hal. 1. 
diterima oleh para pihak yang bersengketa. Karena itu proses mediasi adalah proses yang forward looking dan bukan backward looking. Yang hendak dicapai bukanlah mencari kebenaran dan/atau dasar hukum yang diterapkan, namun lebih kepada penyelesaian masalah. The goal is not truth finding or law imposing, but problem solving. ${ }^{45}$

${ }^{45}$ Ibid., hal. 3. 


\section{Daftar Pustaka}

\section{Bahan Hukum Primer}

Indonesia. UU tentang Arbitrase dan Alternatif Penyelesaian Sengketa. UU No. 30 Tahun 1999. LN RI Tahun 1999 No. 138, TLN RI No. 3872.

Bank Indonesia. Peraturan Bank Indonesia tentang Mediasi Perbankan. Peraturan Bank Indonesia No. 8/5/PBI/2006. LN RI Tahun 2006 No. 7, TLN RI No. 4601.

Peraturan Bank Indonesia tentang Perubahan Atas Peraturan Bank Indonesia No. 8/5/PBI/2006 tentang Mediasi Perbankan. Peraturan Bank Indonesia No. 10/1/PBI/2008.LN RI Tahun 2008 No. 10, TLN RI No. 4808.

\section{Buku}

Djumhana, Muhammad. Hukum Perbankan di Indonesia, Bandung: PT. Citra Aditya Bhakti, 2003.

Hardanto, Sulad Sri. Manajemen Risiko bagi Bank Umum, Cet. II. Jakarta: PT. Elex Media Komputindo, 2007.

Husein, Yunus dan Zulkarnain Sitompul. Hukum Perbankan 1, Jakarta: Program Pascasarjana Fakultas Hukum Universitas Indonesia, 2001.

. Hukum Perbankan 2, Jakarta: Program Pascasarjana Fakultas Hukum Universitas Indonesia, 2001.

Samsul, Inosentius. Perlindungan Konsumen, Kemungkinan Penerapan Tanggung Jawab Mutlak, Cet.I. Jakarta: Program Pascasarjana Fakultas Hukum UI, 2004.

Rae, Dian Ediana. Transaksi Derivatif dan Masalah Regulasi Ekonomi di Indonesia, Jakarta: PT. Elex Media Komputindo, 2008.

\section{Artikel}

Soebagjo, Felix Oentoeng. Mediasi Sebagai Alternatif Penyelesaian Sengketa di bidang Perbankan. Bahan Diskusi Terbatas "Pelaksanaan Mediasi Perbankan oleh Bank Indonesia dan Pembentukan Lembaga Independen Mediasi Perbankan". Kerjasama Magister Hukum Bisnis dan Kenegaraan UGM dan BI, 21 Maret 2007. 
Sujatmiko, Tomi. Mencari Bentuk Ideal Lembaga Mediasi Perbankan Masa Depan, "Koran Sindo", 7 januari 2008.

\section{Internet}

"Ayo Ke Bank, Mediasi Perbankan", <http://www.bi.go.id>, diakses tanggal 28 November 2008.

"BI Ingin Tangani Sengketa Nasabah", <http://web.bisnis.com/edisicetak/edisi-harian/keuangan/lid38577.html>, diakses tanggal 12 Januari 2008.

"Lembaga Mediasi Perbankan Gagal Dibentuk Tahun Ini", $<$ http://www.hukum-online.com/detail.asp?id=17353\&cl= Berita $>$, diakses tanggal 13 Agustus 2008.

Faj. "BI Akan Bentuk Mediasi Perselisihan Perbankan", $<$ http://64.203.71.11/-kompas-cetak/0407/31/finansial/1180270 .htm>, diakses tanggal 31 Juli 2004.

Ghufron, Muchamad. "Lembaga Mediasi Lepas Dari BI", $<$ http://jurnalnasional-.com/med $=$ Koran $\% 20$ Harian\&sec $=$ Ekonomi\%20Makro\&rbrk=\&id=>, diakses tanggal 1 April 2008.

Hadad, Muliaman D. "Perlindungan dan Pemberdayaan Nasabah Bank Dalam Arsitektur Perbankan Indonesia“, <http://www.bi.go.id >, diakses tanggal 10 November 2008.

Husein, Yunus. "Pelajaran dari Krisis Keuangan Amerika", $<$ http://www.economy-.okezone.com/index.php/ReadStory/ 2008/10/07/212/15-1437/pelajaran-dari-krisis-keuangan-amerika>, diakses tanggal 7 Oktober 2008.

Kuncoro, Wahyu. "Lembaga Mediasi Perbankan", <http://advokatku. blogspot-.com/2007/09/lembaga-mediasi-perbankan.html>, diakses tanggal 14 September 2007.

Lastania, Ezther. "Perbankan Didesak Atasi Sengketa", $<$ http://www.tempo/co.id-/hg/ekbis/2008/03/31/brk,2008331-120145 ,id.html>, diakses tanggal 31 Maret 2008.

Priliasari, Erna. "Mediasi Perbankan Sebagai Wujud Perlindungan Terhadap Nasabah", <www.legalitas.org>, diakses tanggal 10 November 2008. 
Rahman, Habibur. "Perbankan Gagal Bentuk Lembaga Mediasi", Surya Online, 11 Januari 2008.

Sitompul, Zulkarnain. "Peran dan Fungsi Bank Dalam Sistem Perekonomian", <http://zulsitompul.wordpress.com/>, diakses tanggal 29 November 2008.

Sut. "BI Desak Perbankan Segera Bentuk Lembaga Mediasi", <http://www.hukumonline.com/detail.asp?id=18483\&cl=Berita $>$, diakses tanggal 5 Februari 2008.

. "BI Lebih Punya Wibawa", <http://www.hukumonline.com/ de-tail.asp?id=20-195\&cl=Berita $>$, diakses tanggal 30 September 2008.

Thirzano, Yudhie. "Menanti Lembaga Mediasi Independen, Masih Terkendala SDM dan Pendanaan", <http://www.surya.co.id/web>, diakses tanggal 1 Maret 2008.

Tularji. "Lembaga Mediasi, Sengketa Nasabah vs Bank", $<$ http://web.bisnis.com/>, diakses tanggal 22 Februari 2008.

Umam, Khotibul. "Catatan Kritis Terhadap PBI No. 8/5/PBI/2006 tentang Mediasi Perbankan Sebagai Alternatif Penyelesaian Sengketa dan Rekomendasi Dalam Implementasinya ke Depan", $<$ http://khotibwriteinc.blog-spot.com/2008/03/me-diasiperbankan.html>, diakses tanggal 28 Maret 2008.

Williarsih, Sefti. "Perlindungan Kepentingan Nasabah dan Pentingnya Menjaga Reputasi Bank", <http://akuasih.wordpress.com/ 2008/03/08/-mediasiperban-kan/>, diakses tanggal 8 Maret 2008. 